\title{
FAKTOR-FAKTOR YANG MEMENGARUHI PROFITABILITAS PERUSAHAAN MANUFAKTUR YANG LISTED DI BURSA EFEK INDONESIA
}

\author{
Winarno, Lina Nur Hidayati, \& Arum Darmawati \\ Universitas Negeri Yogyakarta, Indonesia \\ Email:winarno@uny.ac.id
}

\begin{abstract}
Abstrak: Faktor-Faktor yang Memengaruhi Profitabilitas Perusahaan Manufaktur yang Listed di Bursa Efek Indonesia. Penelitian ini bertujuan untuk mengetahui pengaruh pangsa pasar (market share), leverage, intensitas modal, pertumbuhan penjualan dan total assets baik secara parsial maupun simultan terhadap profitabilitas perusahaan manufaktur yang listed di Bursa Efek Indonesia. Penelitian ini termasuk penelitian kausalitas, sampel yang digunakan 86 perusahaan dan 329 pengamatan. Data diambil dengan metode purposive sampling. Intensitas modal dan total assets berpengaruh positif dan signifikan terhadap profitabilitas, sedangkan market share (pangsa pasar), leverage dan pertumbuhan penjualan tidak berpengaruh terhadap profitabilitas.
\end{abstract}

Kata Kunci: Market Share, Leverage, Intensitas Modal, Pertumbuhan penjualan, Total Assets, Profitabilitas

\begin{abstract}
Determinant Factors Influencing The Profitability of Manufacturing Companies Listed on The Indonesia Stock Exchange. This research aimed to know the influence of market share, Leverage, Capital Intensity, growth of sales and Total Assets either partially or simultaneous to the profitability of the manufacturing companies listed on the Indonesia Stock Exchange. This research included research of causality, the sample used 86 companies and 329 observations. The data were taken with purposive sampling method. The intensity of capital and total assets turnover had a positive and significant effect on profitability, while market share, leverage and sales growth had no effect on the profitability.
\end{abstract}

Keywords: Market Share, Leverage, Intensity of Capital and Total Assets, Profitability

\section{PENDAHULUAN}

Dalam setiap bisnisnya perusahaan pasti menginginkan laba. Kemampuan untuk memperoleh laba dalam dunia bisnis disebut dengan profitabilitas. Profitabilitas perusahaan sangat ditentukan oleh faktor internal dan eksternal perusahaan. Faktor internal meliputi kemampuan manajemen, kompetensi karyawan, sistem reward dan punishment, asset yang digunakan, utang, penjualan serta kompetensi perusahaan menurut pendekatan resources based views. Faktor eksternal menurut Porter (1979) dalam Grant (1997) disebut dengan struktur pasar. Struktur Pasar dikenal dengan five forces model porter's. Struktur Pasar perusahaan meliputi: a) hambatan masuk pasar, b)persaingan dalam pasar yang sudah ada, c) barang substitusi, d) kekuatan tawar pembeli dan e) kekuatan tawar pemasok.

Profitabilitas adalah kemampuan perusahaan memperoleh Laba. Ada berbagai ukuran dari Profitabilitas yaitu: a) Return on Equity (ROE) yang merupakan rasio atau perbandingan antara Earnings After Taxes (EAT) dengan Equity. b) Return on Asset 
(ROA) yang merupakan perbandingan antara Earnings After Taxes (EAT) dengan Total Asset. Profitabilitas merupakan ukuran kinerja dari suatu organisasi yang profit oriented. Untuk melihat kinerjanya perusahaan dapat melakukan benchmark internal dengan kinerja tahun sebelumnya atau dengan benchmark eksternal dengan rasio industri.

Pangsa Pasar (Market Share) merupakan rasio antara Penjualan perusahaan tertentu dengan Penjualan Total Industri. Pangsa Pasar mewakili variabel struktur pasar yaitu persaingan dalam suatu pasar/industri tertentu, menunjukkan tingkat konsentrasi dari pasar/industri yang bersangkutan. Perusahaan yang memiliki pangsa pasar yang besar akan lebih mudah memperoleh laba.

Intensitas Modal merupakan rasio antara Penjualan dengan Total Asset. Rasio ini menunjukkan tingkat efisiensi penggunaan asset oleh perusahaan. Rasio ini merupakan hambatan masuk bagi perusahaan baru. Perusahaan baru yang akan memasuki pasar oligopoli harus memiliki tingkat efisiensi yang tinggi, kalau tidak perusahaan tersebut tidak akan mampu memasuki pasar yang baru. Perusahaan yang memiliki tingkat efisiensi yang tinggi tentunya akan lebih mudah memperoleh laba. Rasio ini mencerminkan kemampuan perusahaan menggunakan assetnya untuk menghasilkan penjualan. Semakin tinggi rasio ini berarti semakin efisien penggunaan aktiva tersebut. Namun perusahaan juga harus melihat kepada rasio intensitas modal industri. Apabila rasio intensitas modal terlalu tinggi bukan berarti rasio ini baik tetapi nilai asset terlalu rendah, sehingga harus dilakukan penggantian. Penggunaan secara optimal aktiva akan meningkatkan laba perusahaan. Dengan demikian ada pengaruh positif intensitas modal terhadap Profitabilitas.

Utang (Leverage) merupakan salah satu sumber dana yang berasal dari luar/kreditur yang dapat digunakan perusahaan untuk menopang operasional bisnis perusahaan. Utang digunakan karena ada manfaatnya yaitu dapat mengurangi pendapatan kena pajak. Dalam situasi perekonomian yang normal/stabil utang akan meningkatkan nilai perusahaan karena manfaat dari utang lebih besar daripada biaya bunga yang harus dibayarkan kepada kreditur. Tetapi dalam situasi perekonomian yang tidak normal/tidak stabil penggunaan utang akan membebani perusahaan dengan beban tetap, yang berdampak mempersulit posisi perusahaan. Dalam situasi perekonomian yang normal seperti sekarang ini utang akan memiliki manfaat yang lebih tinggi daripada biaya bunga yang harus dibayar, sehingga penggunaan utang akan dapat meningkatkan laba perusahaan. Perusahaan menggunakan utang, jika manfaat dari utang lebih tinggi dari biaya bunga yang harus dibayarkan kepada kreditur. Penggunaan utang akan menambah sumber dana bagi perusahaan, sehingga perusahaan dapat lebih memaksimalkan kesempatan bisnis yang ada. Penggunaan utang secara optimal akan membuat biaya modal minimal dan harga saham maksimal. Dengan demikian leverage (utang) akan berpengaruh positif terhadap laba.

Pertumbuhan penjualan yang positif mencerminkan kinerja perusahaan yang semakin baik, artinya penjualan tahun sesudahnya lebih tinggi daripada penjualan 
tahun sebelumnya. Semakin tinggi pertumbuhan penjualan yang dicapai semakin tinggi laba yang akan diterima, sehingga ada pengaruh positif pertumbuhan penjualan terhadap profitabilitas

Total asset juga merupakan hambatan masuk pasar. Artinya di suatu pasar yang mensyaratkan total asset yang besar, akan sulit dimasuki oleh perusahaan kecil. Semakin sedikit perusahaan yang mampu memasuki suatu pasar akan semakin meningkatkan konsentrasi pasar. Semakin terkonsentrasi pasar, semakin tinggi laba yang akan diperoleh oleh perusahaan yang ada. Dengan demikian ada pengaruh positif total asset terhadap profitabilitas.

Martono (1997) menganalisis pengaruh profitabilitas industri, rasio leverage keuangan tertimbang dan intensitas modal tertimbang serta pangsa pasar terhadap ROA dan ROE perusahaan manufaktur yang go public di Indonesia. Hasil penelitian tersebut menyatakan bahwa: 1) ROA industri berpengaruh positif dan signifikan terhadap ROA perusahaan manufaktur, intensitas modal tertimbang berpengaruh negatif dan signifikan terhadap ROA perusahaan manufaktur dan leverage keuangan tertimbang berpengaruh negatif dan signifikan terhadap ROA perusahaan manufaktur. Pangsa pasar tidak berpengaruh terhadap ROA perusahaan manufaktur 2) ROE industri berpengaruh positif dan signifikan terhadap ROE perusahaan manufaktur, leverage keuangan tertimbang berpengaruh negatif terhadap ROE perusahaan manufaktur dan pangsa pasar berpengaruh positif dan signifikan terhadap ROE perusahaan manufaktur. Rasio intensitas modal tertimbang tidak berpengaruh terhadap ROE perusahaan manufaktur.

Umi Murtini dan Dwi Setia Anggraini (2006) meneliti tentang pengaruh pangsa pasar, rasio leverage dan rasio intensitas modal terhadap profitabilitas perusahaan manufaktur yang go public di Indonesia. Hasil penelitian(Hipotesis I) menunjukkan pangsa pasar tidak berpengaruh terhadap ROA perusahaan manufaktur, Total debt to total assets (DTA) berpengaruh positif dan signifikan ROA perusahaan manufaktur, Debt to Equity ratio (DER) tidak berpengaruh terhadap ROA perusahaan manufaktur. Rasio intensitas modal berpengaruh negatif dan signifikan terhadap ROA perusahaan manufaktur. Hipotesis II menunjukkan bahwa pangsa pasar tidak berpengaruh terhadap ROE perusahaan manufaktur. Rasio Total debt to total assets (DTA) berpengaruh negatif dan signifikan terhadap ROE perusahaan manufaktur, DER berpengaruh negatif dan signifikan terhadap ROE perusahaan manufaktur, Rasio intensitas modal berpengaruh positif dan signifikan terhadap ROE perusahaan manufaktur.

Dony Abdul Chalid dan Liyu Adhika Sulung (2007) meneliti tentang Struktur Pasar dan Profit Industri Manufaktur Indonesia. Hasil penelitiannya menunjukkan bahwa; 1) market share berpengaruh negatif dan signifikan terhadap rate of return. Concentration ratio berpengaruh positif terhadap rate of return, Aset berpengaruh positif dan signifikan terhadap rate of return, Advertising berpengaruh positif dan signifikan terhadap rate of return, sedangkan Growth tidak berpengaruh terhadap rate of return. 
Ambar Pangestu Rini (2007) meneliti pengaruh perubahan modal kerja, pangsa pasar dan rasio leverage serta rasio intensitas modal terhadap profitabilitas pada perusahaan manufaktur di Bursa Efek Jakarta. Hasil penelitian menunjukkan bahwa: 1) perubahan modal kerja tidak berpengaruh terhadap ROE perusahaan manufaktur, 2) Pangsa Pasar berpengaruh positif dan signifikan terhadap ROE perusahaan manufaktur, 3) rasio leverage berpengaruh positif dan signifikan terhadap ROE perusahaan manufaktur, 4) rasio intensitas modal berpengaruh positif dan signifikan terhadap ROE perusahaan manufaktur.

Adapun tujuan dari penelitian ialah untuk mengetahui pengaruh Pangsa Pasar, Leverage, Intensitas Modal dan Pertumbuhan Penjualan dan Total Asset secara parsial dan simultan terhadap Profitabilitas perusahaan manufaktur yang terdaftar di Bursa Efek Indonesia.

\section{METODE}

Penelitian ini termasuk penelitian kausalitas jika dilihat dari hubungan antar variabel. Variabel dependen yang digunakan adalah profitabilitas, sedangkan variabel independennya adalah pangsa pasar, leverage, intensitas modal, pertumbuhan penjualan dan total asset. Berdasar data yang digunakan termasuk penelitian kuantitatif.

Sampel yang digunakan adalah perusahaan manufaktur yang listed di Bursa Efek Indonesia Periode 2008-2011. Metode pengambilan sampel dengan purposive sampling dengan kriteria: 1 . data tersedia selama tahun pengamatan (2007-2012). 2.
Laba perusahaan positif. Adapun metode pengumpulan data dengan dokumentasi, artinya data mengenai variabel dependen dan independen diambil dari IDX dan ICMD.

Teknik analisis data menurut Ghozali (2009) dilakukan dengan uji prasyarat analisis meliputi: 1) Uji normalitas data untuk mengetahui apakah data bersifat normal atau tidak. Bila data normal maka dapat digunakan statistik parametrik tetapi apabila data tidak normal menggunakan statistik non parametrik. Uji normalitas menggunakan one sample KolmogorovSmirnov. 2) Uji Asumsi Klasik. Uji asumsi klasik meliputi: a) uji multikolinearitas untuk mengetahui apakah antar variabel independen terdapat korelasi yang kuat. Cara mendeteksi multikolinearitas dengan melihat koefisien korelasi antar variabel bebas. Jika korelasi antar variabel bebas lebih besar dari 0,7 maka terjadi multikolinearitas atau dengan melihat nilai VIF (Variance Inflation Factor). Jika nilai VIF melebihi 4 maka terjadi multikolinearitas. b) Uji autokorelasi menggunakan Durbin Watson. Dalam uji ini untuk mengetahui apakah ada korelasi antara anggota serangkaian data observasi yang diuraikan menurut waktu atau ruang. c) Uji heteroskedastisitas menggunakan uji Glejser. Dalam uji ini untuk memastikan bahwa varians dalam model sama/konstan. Teknik analisis data yang digunakan dalam penelitian ini adalah regresi linear berganda. Adapun model yang digunakan adalah $\mathrm{Y}=\mathrm{a}+\mathrm{b}_{1} \mathrm{X} 1+\mathrm{b}_{2} \mathrm{X} 2+\mathrm{b}_{3} \mathrm{X} 3+\mathrm{b}_{4} \mathrm{X} 4+\mathrm{b}_{5} \mathrm{X} 5+\mu$

\section{HASIL DAN PEMBAHASAN}

Untuk membuktikan hipotesis yang telah diajukan, peneliti selanjutnya menentukan 
populasinya yaitu perusahaan manufaktur yang listed di BEI periode 2007 sampai dengan 2012. Dari sejumlah 154 perusahaan manufaktur diambil 86 perusahaan sebagai sampel (329 pengamatan). Pengambilan sampel ini berdasarkan purposive sampling dengan kriteria sebagai berikut: 1 . data tersedia selama tahun pengamatan (20072012). 2. Laba perusahaan positif.

Awalnya diperoleh pengamatan 471, tetapi ada data outlier (ROE melebihi 100\%, pertumbuhan penjualan melebihi 100\%), maka data tersebut dihilangkan. Selanjutnya diperoleh 329 pengamatan. Dari hasil statistik deskriptif dapat disimpulkan bahwa: Return on Equity (ROE) nilai rata-ratanya 0,1494, standar deviasi 0,09588, nilai maksimum 0,47 dan minimum 0,01. Data ROE homogen karena nilai rata-rata lebih besar daripada nilai standar deviasinya. Market Share nilai rata-ratanya 0,1333, standar deviasi 0,13813, nilai maksimum 0,64 dan minimum 0,01. Data Market Share heterogen karena nilai rata-ratanya lebih kecil daripada nilai standar deviasinya. Debt Equity Ratio nilai rata-ratanya 1,3205, standar deviasi 1,88750, nilai maksimum 20,87 dan minimum 0,08. Data Debt Equity Ratio heterogen karena nilai rata-ratanya lebih kecil daripada nilai standar deviasinya. Total Asset Turnover nilai rata-ratanya 1,2553, standar deviasi 0,55750, nilai maksimum 4,14 dan minimum 0,21. Data Total Asset Turnover homogen karena nilai rata-ratanya lebih besar daripada nilai standar deviasinya. Growth Sales nilai rataratanya 0,1270, standar deviasi 0,18094, nilai maksimum 0,56 dan minimum -0,48. Data Growth Sales heterogen karena nilai rata-ratanya lebih kecil daripada nilai standar deviasinya. Size nilai rata-ratanya 6,1825, standar deviasi 0,60788, nilai maksimum 8,19 dan minimum 4,79. Data Size homogen karena nilai rata-ratanya lebih besar daripada nilai standar deviasinya.

Sebelum melakukan analisis regresi linear berganda, dilakukan pengujian asumsi klasik. Uji normalitas dalam penelitian ini menggunakan uji Kolmogorov-Smirnov. Hasilnya diperoleh bahwa nilai KolmogorovSmirnov 1,152 dengan nilai signifikansi 0,141 , artinya data berdistribusi normal karena nilai signifikansi melebihi 0,05. Model ini juga terbebas dari multikolinearitas karena nilai VIF yang ditemukan kurang dari 4. Hasil uji heterosedastisitas dengan uji Glesjer juga menghasilkan nilai signifikansi yang lebih dari 0,05 sehingga model ini memenuhi syarat. Begitu juga hasil uji autokorelasi ditemukan nilai Durbin-Watson 1,895. Nilai tersebut berada di antara nilai $\mathrm{Du}=1,820$ dan $\mathrm{DI}=1,718$, sehingga tidak ada autokorelasi positif dan negatif. Dengan demikian seluruh asumsi klasik yang dipersyaratkan dapat dipenuhi dalam model ini.

Hasil analisis regresi menghasilkan bahwa secara simultan seluruh variabel independen berpengaruh terhadap ROE dengan nilai Adjusted $R$ Square sebesar 0,054 dan $\mathrm{F}$ sebesar 4,73 (sig $<0,001$ ). Oleh karena itu perlu diuji secara parsial pengaruh masing-masing variabel independen terhadap variabel dependen (Tabel 1).

Berdasarkan Tabel 1 diketahui bahwa market share (pangsa pasar) memiliki koefisien 0,042 dan nilai signifikansi 0,335, sehingga pangsa pasar tidak memiliki pengaruh yang signifikan terhadap 
Tabel 1. Hasil Analisis Regresi Ganda

\begin{tabular}{|c|c|c|c|c|c|c|}
\hline \multirow[b]{2}{*}{ Mod } & & \multicolumn{2}{|c|}{$\begin{array}{l}\text { Unstandardized } \\
\text { Coefficients }\end{array}$} & \multirow{2}{*}{$\begin{array}{c}\text { Standardized } \\
\text { Coefficients } \\
\text { Beta }\end{array}$} & \multirow[b]{2}{*}{$\mathrm{t}$} & \multirow[b]{2}{*}{ Sig. } \\
\hline & & B & Std. Error & & & \\
\hline \multirow[t]{6}{*}{1} & (Constant) & -.071 & .063 & & -1.132 & .259 \\
\hline & MS & .042 & .043 & .061 & .966 & .335 \\
\hline & DER & -.004 & .003 & -.081 & -1.490 & .137 \\
\hline & TAT & .023 & .010 & .133 & 2.380 & .018 \\
\hline & GS & .010 & .029 & .018 & .331 & .741 \\
\hline & SIZE & .031 & .010 & .195 & 3.052 & .002 \\
\hline
\end{tabular}

a. Dependent Variable: ROE

profitabilitas. Hal ini sesuai dengan penelitian Martono (1997) dan Umi Murtini dan Dwi Setia Anggraini (2006) yang mengatakan bahwa pangsa pasar tidak berpengaruh terhadap profitabilitas. Penyebab tidak signifikannya pengaruh pangsa pasar terhadap profitabilitas, disebabkan dari data yang heterogen. Hal ini dapat dilihat dari data statistik deskriptif yang menunjukkan nilai standar deviasi $(0,13813)>$ mean $(0,1333)$.

Leverage memiliki koefisien $-0,004$ dan nilai signifikansi 0,137 , sehingga Leverage tidak memiliki pengaruh yang signifikan terhadap profitabilitas. Hal ini sesuai dengan penelitian Umi Murtini dan Dwi Setia Anggraini (2006) yang mengatakan bahwa Leverage tidak berpengaruh terhadap profitabilitas. Penyebab tidak signifikannya pengaruh Leverage terhadap profitabilitas, disebabkan dari data yang heterogen. Hal ini dapat dilihat dari data statistik deskriptif yang menunjukkan nilai standar deviasi $(1,88750)>$ mean $(1,3205)$.

Hasil pengujian menemukan bahwa intensitas modal memiliki koefisien 0,023 dan nilai signifikansi 0,018 , sehingga intensitas modal memiliki pengaruh positif dan signifikan terhadap profitabilitas. Hal ini bertentangan dengan penelitian Martono (1997) dan Umi Murtini dan Dwi Setia Anggraini (2006) yang mengatakan bahwa Intensitas Modal memiliki pengaruh negatif dan signifikan terhadap profitabilitas. Intensitas modal juga berarti efisiensi yang dicapai oleh perusahaan. Implikasi dari hasil penelitian ini adalah: apabila Manajemen perusahaan akan meningkatkan laba perusahaan, maka harus meningkatkan intensitas modalnya. Hal ini juga berarti hambatan masuk bagi pendatang baru yang ingin memasuki pasar yang selama ini sudah dilayani oleh perusahaan yang sudah ada.

Pertumbuhan Penjualan memiliki koefisien 0,010 dan nilai signifikansi 0,741, sehingga Pertumbuhan Penjualan memiliki pengaruh positif tetapi tidak signifikan/tidak berpengaruh terhadap profitabilitas. Hal ini sesuai dengan penelitian Dony Abdul Chalid dan Liyu Adhika Sulung (2007) yang mengatakan bahwa Pertumbuhan Penjualan tidak berpengaruh terhadap profitabilitas. Menurut Jogiyanto (2004), penyebab tidak signifikannya pengaruh suatu variable independen terhadap dependen karena tidak homogennya data. Pengaruh variabel Pertumbuhan Penjualan terhadap profitabilitas yang tidak signifikan, diduga 
karena data yang heterogen. Hal ini dapat dilihat dari data statistik deskriptif yang menunjukkan nilai standar deviasi $(0,18094)$ $>$ mean $(0,1270)$.

Total Asset memiliki koefisien 0,031 dan nilai signifikansi 0,002, sehingga total asset memiliki pengaruh positif dan signifikan terhadap profitabilitas. Hal ini sesuai dengan penelitian Dony Abdul Chalid dan Liyu Adhika Sulung (2007). Implikasi dari hasil penelitian ini adalah: apabila Manajemen perusahaan akan meningkatkan laba perusahaan, maka harus meningkatkan total assetnya. Dalam konteks strategi hal ini juga berarti hambatan masuk bagi pendatang baru yang ingin memasuki pasar yang selama ini sudah dilayani oleh perusahaan yang sudah ada. Implikasi yang lain perusahaan yang memiliki size/total asset yang besar akan memiliki kemudahan dalam mengakses sumber dana, misalnya pasar modal.

\section{SIMPULAN}

Berdasarkan hasil penelitian maka dapat disimpulkan bahwa market share (pangsa pasar), leverage, dan pertumbuhan penjualan secara parsial tidak memiliki pengaruh yang signifikan terhadap profitabilitas, sedangkan intensitas modal dan total asset secara parsial memiliki pengaruh positif dan signifikan terhadap profitabilitas. Hal ini mengindikasikan bahwa profitabilitas perusahaan lebih banyak ditentukan oleh intensitas modal dan total asset dibandingkan pangsa pasar, leverage, dan pertumbuhan penjualan.

\section{DAFTAR PUSTAKA}

Ambar Pangestu Rini (2007) Pengaruh Perubahan Modal Kerja, Pangsa Pasar, Rasio Leverage, dan Rasio Intensitas Modal Terhadap Profitabilitas Pada Perusahaan Manufaktur Di Bursa Efek Jakarta, Skripsi. FISE, UNY.

Dony Abdul Chalid dan Liyu Adhikasari Sulung (2007) Struktur Pasar dan Profit Manufaktur Indonesia. Usahawan No 12 th XXXVI. 28-35.

Grant, Robert M. (1997) Analisis Strategi Kontemporer. Jakarta: Erlangga.

Imam Ghozali (2009) Ekonometri. Semarang: Badan Penerbit UNDIP.

Indonesian Capital Market Directory Tahun 2009, 2012. Jakarta: Bursa Efek Indonesia.

Jogiyanto, HM. (2004) Metodologi Penelitian Bisnis. Yogyakarta: BPFE.

Martono, C. (1997) Analisis Pengaruh Profitabilitas Industri, Rasio Leverage Keuangan Tertimbang, dan Intensitas Modal Tertimbang serta Pangsa Pasar terhadap ROA dan ROE Perusahaan Manufaktur yang Go Public di Indonesia. Jurnal Akuntansi. Univ Petra.

Umi Murtini \& Dwi Setia Anggraeni (2006) Pengaruh Pangsa Pasar, Rasio Leverage, dan Rasio Intensitas Modal Terhadap Profitabilitas Perusahaan Manufaktur yang Go Public di Indonesia. Jurnal Riset Akuntansi dan Keuangan Volume 2. Februari 2006. 27-36. 